\title{
A Thorough Analysis of the Effects of Foreign Direct Investment on the Financial Account of the Iraqi Balance of Payments for the Period (2003-2015)
}

\author{
Amna Al-Ameeri", Hanaa Al Samarai \\ Central Bank of Iraq, Baghdad, Iraq \\ Email address: \\ amna_alameeri@outlook.com (A. Al-Ameeri) \\ ${ }^{*}$ Corresponding author
}

\section{To cite this article:}

Amna Al-Ameeri, Hanaa Al Samarai. A Thorough Analysis of the Effects of Foreign Direct Investment on the Financial Account of the Iraqi Balance of Payments for the Period (2003-2015). Journal of World Economic Research. Vol. 6, No. 3, 2017, pp. 34-45. doi: 10.11648/j.jwer.20170603.12

Received: March 8, 2017; Accepted: March 30, 2017; Published: May 25, 2017

\begin{abstract}
In order to analyze the direct and indirect effects of the foreign direct investment on the Iraqis balance of payments and financial account for the period (2003-2015), the study population and sample selected was the Balance of Payments Division at the Central Bank of Iraq through the follow-up of the entry of the data incoming from the relevant parties like banks and Iraq Stock Exchange in order to calculate the foreign direct investment through sorting and isolating the transactions that are classified under this part of the balance of payments and then registering the value of the transaction in the balance of payments as credit or debit transaction. The research methodology used a sample represented by the Balance of Payments Compilation Guide issued by the International Monetary Fund. A study was conducted to compare the fifth edition of the guide that was issued in 1993 and the sixth edition that was released in 2009. The study concluded that the outflows of foreign direct investment from Iraq were relatively weak as they did not exceed USD1,562.4, representing only 7.4\% of total capital inflows to Iraq, which is also small relatively and its share of total foreign direct investment inflows to Arab countries ranged from $1.2 \%$ in 2007 to $10.7 \%$ in 2014 . Hence, the effect of the flows of foreign direct investment both inside and outside Iraq on the financial account in particular and the balance of payment in general was weak. Even though the primary effect of the inflows might be positive, the effect was negative on all items of the financial account and balance of payment in general during the whole period. In other words, the obligations resulting from the inflows are bigger than their counterpart from the outflows. The study recommended adopting and setting some certain mechanisms to ensure the transmission of the effects of the international economy through the foreign direct investment into the domestic economy and the real sectors. Consequently, the financial account of the balance of payments is initially affected. In turn indirect impacts take place on the current account and service account through affecting the macro variables like the gross fixed capital formation that is considered a productive capacity that could be utilized to increase production and attain positive growth.
\end{abstract}

Keywords: Iraqi Economy, Iraqi BOP, Foreign Direct Investments, Iraq

\section{Introduction}

The need for financing investment in the developing countries appear from the foreign direct investment. This is more evident in the countries that are transmitting into the market economy, because this type of investment gives an important impetus to the global integration through contributing to interlinking capital and labor markets, besides raising wages and the productivity of capital in the countries hosting the capital. Therefore, the foreign direct investment plays an important role in the economic and social development process and contributes actively in the economic reform agenda.

The International Monetary Fund's Balance of Payments Compilation Guide is an international reference and a common standard for the conceptual framework on which the preparation of balance of payments statistics depend. The member countries in the Fund consult the guide when 
preparing their required periodic reports. The main goal of this compilation guide is facilitating the preparation and compilation of balance of payments statistics and the position of the international investment on domestic and global levels methodically in a way that allows for making comparisons through setting common standards for the concepts, definitions, classifications and practices. The International Monetary Fund focuses on setting and releasing guiding principles for preparing consistent and valid balance of payments statistics. This guide is the foundation for the other responsibilities of the Fund, including regulatory measures on the economic policies of countries, and for the provision of technical assistance to enable the member countries to overcome short-term problems in their balance of payments.

\section{Research Motivation}

This research has a special importance to Iraq due to the situation that the country is facing form one hand and the nature of the institutional framework in Iraq on another hand. The country is suffering from many problems that mandates a comprehensive economic reform targeting the attraction of foreign direct investment surpassing the obstacles facing this investment in order to end the unfavorable situation for local economic capabilities towards the success of the economic development that has failed because of the inappropriate policies that generated a large and difficult economic, political and legal barriers to the entry of foreign direct investment to Iraq.

\section{Research Problem}

The comparison of the inflows and outflows of foreign direct investment for a certain country might give a clear image of its importance and advantages. In addition, the measures that are adopted by the hosting countries in general to attract capital or reinvest profits may have positive outcomes for the economy as attaining favorable outcomes requires that the foreign investor does not have the highest share of the increase in the national income. Besides that, appropriate policies and measures must be adopted to ensure the transmission of the international economy impacts into the domestic economy.

\section{Research Hypothesis}

The impact of the flows of foreign direct investments in and out of Iraq on Iraqi's financial account and balance of payments is not material. There are therefore no guarantees that the effects of the international economy transmit into the domestic Iraqi economy.

\section{Research Objective}

a) Explaining the method of measurement and the mechanism of evaluating, recording and calculating the foreign direct investment in the Central Bank of Iraq in the financial component of the balance of payments that is represented by the flows of foreign capital into the country and their balances from one side and the outflows from the other side.

b) Identifying the direct and indirect effects of the inflow of foreign direct investment as a primary source for domestic resources gap.

\section{Research Limits}

a) Location limits: Central Bank of Iraq - Balance of Payment Division.

b) Time limits: the time limits includes the period (20032015) limited by data availability.

\section{Research Population and Sample}

The research and population sample includes:

a) The International Monetary Fund's Balance of Payments compilation guide for preparing the balance of payments statistics based on the fifth edition of 1993 and the sixth edition of 2009 .

b) The Iraqi balance of payments statistics record for the period (2003-2015).

c) The record of the balance of payments financial account.

\section{Foreign Direct Investment}

\subsection{Definition and Importance of Foreign Direct Investment}

Literature and international organizations put several definitions of foreign direct investment. Each entity focuses on some aspects of the definition. However, these definitions indicate that it represents the transmission of capitals through a set of flows to the receiving countries in order to maximize profits and attain the desired benefits in partnership with the domestic capital to build different projects in these countries. The importance of investment in the receiving countries as it is an important source of funding sources and contributes in reforming the economy, stabilizing the inflation and producing new commodities that contribute in developing exports and obtaining foreign currency [1]. Regarding its importance for the foreign investor, it represents an activity for the expansion and growth and the benefiting from the low labor cost advantage and the availability of raw materials and various benefits and facilities in the receiving countries, in addition to mitigating the risk by diversifying activities and markets [2].

\subsection{Investment Climate Concept}

The World Bank defines investment climate as a set of factors related to a specific location that allows the companies to invest in a productive way, create jobs and expand. The economic policies play a significant role in affecting this climate through their impact on various costs 
and the mitigation of risks and barriers to competition. Investment climate represents the well and the real belief of the political authority in the necessity of attracting foreign investment so that they lead to adopting encouraging measures in all aspects.

\subsection{International Indicators for Evaluating Investment Climate in Iraq}

Several international institutions and agencies have developed specific indicators that help the investor differentiate between the various countries and selecting the best conditions and requirements that provide and ensure the safety of his investments and increase his profits. In the application of the most important indicators on the business environment in Iraq, the results have indicated the following:

a) Regarding the general index of the ease of doing business, the ranking of Iraq dropped from 141 in 2007 to 161 in 2015 among 181 international economy signaling the existence of serious obstacles that the investment activity suffer from in Iraq.

b) The composite index of the economic policies components of the investment climate indicated that there was no realizable improvement for the two indices of internal and external balance policy and the monetary policy index.

c) Regarding the investment attractiveness indicator, Iraq is initially classified within the Arab Countries group that ranked fourth among seven international groups. Analyzing the classification of the Arab Countries group reveals that Iraq was classified with the group of the very weak performance that included Mauritania, Yemen and Sudan. This signifies a weakness in attracting foreign investment inflows.

d) Finally, the general picture of the composite indicator of country risks and the instability indicator both indicate the existence of turbulences and instability during the entire indicator period that included 2007, 2010 and 2013.

\section{Opportunities in Iraq and Their Role in Supporting the Iraqi Economy Competitiveness}

The foreign investor finds himself in Iraq confronting diversified investment opportunities in various economic sectors and in production, importing and exporting activities. Moreover, these opportunities are geographically spread in Baghdad and the governorates. Therefore, these opportunities are per se strongly attractive factors that help the foreign investor attain the optimal returns from his investment. On the legal level, the amended Iraqi Investment Law No. (13) for 2006 provided many benefits, guarantees, commitments and exemptions for foreign investors that encompass all sectors except the investments in the extraction and production of oil and natural gas and investments in banking and insurance sectors. Given that all the sectors whether they are covered or not by the law represent significant investment opportunities available to the foreign investors, and could be used to attract these investments. The most important benefits contained in the amended Law No. 13 of 2006 are:

a) The foreign investor enjoys all the benefits, facilities and guarantees that avail to him an equal opportunities as Iraqis.

b) The capital that flowed in Iraq is allowed to flow out of the country along with its returns in accordance with this law and pertinent instructions of the Central Bank of Iraq in a convertible currency.

c) The foreign investor is allowed to invest in Iraq Stock Exchange and form investment portfolios.

d) The foreign investor is allowed to rent the lands needed for his project, as well as insuring the investment project and opening bank accounts in Iraqi Dinar or foreign currency or both inside or outside Iraq.

\section{Principles for Measuring and Registering Foreign Direct Investment in the Financial Account of the BOP}

\subsection{Balance of Payments and Its Structure}

The balance of payments is a record in which economic transactions of a country with the rest of countries are recorded, whether they include the selling or the purchase of goods or services. It also includes the capital transfers that take place between countries, like loans or deposits ...etc. that are done among the residents in a certain country and non-residents (foreigners) in a certain period of time. The importance of the balance of payments lies in its reflection of the strength of the national economy and its ability and degree of adaptability with the changes in the international economy. Generally, the general structure of the balance of payments is composed of four major divisions: current account, capital account, financial account and net errors and emissions.

\subsection{Components of the Financial Account}

The financial account is defined as a record of the mobility of the international capital in which all changes to international assets, possessions or obligations against the others during the balance preparation period are recorded. Included in this account are all operations that represent a change in debit and credit positions for the certain country. [3]

Some literature stated that the financial account is the following special accounts:

a) Foreign direct investment.

b) Investment portfolio (Securities and debt Securities).

c) Other investments (currency exchange deals, bank deposits, commercial letters of credit, etc.).

d) Computational discrepancies. This item is used when preparing the accounting balances or in case an accounting mistake took place in valuing some goods or 
in exchange rates. In special circumstances, the secret confidential transactions for some countries are included under this item like arms deals they are also called errors and emissions.

e) It is important to note that the flows of financial assets and liabilities are recorded on a net basis in international accounts for analytical and practical reasons, as the financial markets are characterized by high trading volumes. Therefore, the financial account focuses on the net balances in every transaction and deducting it from the foreign financial obligations and liabilities that result from the transactions. It might be difficult to enter the data in gross values for some categories and for some financial instruments. The financial account includes the following functional categories:

(Direct investment: registered under the direct investment as a separate item the direct investment from a direct investor to a direct investing company, the reverse investment and the investment among associate institutions). The direct investment is divided into the following:

a) Reinvestment of profits. They are recorded against the equity shares of the direct investor in the direct investment institution as an entry in the financial account. The direct investor's share of the retained earnings or the net saving of the direct investment company before treating the earnings that are reinvested as dividends. This financial account entry item is registered separately under the direct equity investment shares. [4]

b) The in kind direct investment flow. Through the provision of goods, services and other resources from institutions affiliated at prices that are above or below market prices or free of charge. The direct investor might provide machinery and equipment his her direct investment institution. The direct investor may also provide goods or services to the direct investment institution at prices that are below cost in order to increase ownership share in the organization.

c) Mergers and acquisitions. Mergers arise when the two or more companies agree to merge into one company, while acquisitions take place when a company or group of companies buy another company or a group of other companies. This, however, may not result in any new transfers of the companies involved, but might be in the form of a change in investors only.

d) Change the character of companies and other restructuring operations. The restructuring of cross-border institutions group might make the original parent company in one of the economies a subsidiary of the new parent company in another economy. The ownership of the group of the companies transfers to the new parent company. These changes lead to entering financial transactions in the financial account.

e) The distributions of accumulated profits. This is treated as shares withdrawal and not as income payable to the owners. These transactions are eliminated and entered as a withdrawal of shares in the financial account.

f) Borrowing for public finance purposes. The entity that is owned by the public government or that is under its control and resident in another province but used for public finance operations is subject to special rules and is considered and treated as a resident in the economy in which was founded or registered.

\section{The Mechanism of Measuring and Entering the Foreign Direct Investment in the Balance of Payments}

\subsection{Measuring Foreign Direct Investment}

We detail below in paragraphs that are contained in the balance of payments guide issued by the International Monetary Fund in its fifth and sixth editions of 1993 and 2009 respectively that are approved to record these flows. Regarding the fifth edition, the direct investment institutions were defined to include three types of institutions: affiliate institutions (in which the non-resident investor owns more than 50\%), associate institutions (in which the investor has a $50 \%$ or less) and the branches (institutions of limited ownership that are wholly-owned or in partnership) whether directly or indirectly. The affiliate institutions are defined as "the institutions that as subject to foreign control." Whereas the inclusion or exclusion of associate institutions is to be decided by each country based on its assessment of the quality of foreign domination The IMF guide considers a share of $10 \%$ as a benchmark for foreign direct investment, this ratio signifies the influence of the direct investor of the institution and the individual, who has the same property. [5]

The sixth edition of the balance of payments compilation guide defined the direct investment enterprise as an enterprise that is under the absolute control of the direct investor or to a high degree. In some cases, some entity could be at a direct investor, a direct investment enterprise and a fellow enterprise the same time in its relation with the other institutions [6]. Regarding the relationship of the investment institution with the direct investor, the institution could be an affiliate or an associate. In the affiliate institutions, the direct investor has the right to control it, whereas he possess the influence but the control in case of the associate institutions. ${ }^{*}$

\subsection{The Scope of Registering Foreign Direct Investment}

The guide recommends registering the direct capital transactions as well as equity and other types of capital (intercompany loans) on the asset side as maturities and on the liabilities side as obligations, besides net investment transactions who must have separate entries under the direct investment abroad category to record the changes in the dues of the direct investors on the relevant institutions and their

\footnotetext{
* Per the Sixth edition of the Balance of Payments Compilation Guide of the IMF, control or influence may be achieved directly by owning equity that gives voting power in the enterprise, or indirectly by having voting power in another enterprise that has voting power in the enterprise.
} 
obligations towards these institutions and vice versa for direct investment in the economy in which the statement is prepared. The entries are also recorded under the direct investment item in the international investment position. The direct investment income (the rights and the obligations) for both sides is shown on the net basis. The international investment position is classified on two levels. The first is a sectional that distinguish primarily between assets and liabilities whose difference represents the net international investment position. These assets are then divided on a functional basis that is consistent with the key elements of the financial account of the balance of payments. The assets are divided into direct investment, portfolio investment, other investments and assets. [7]

However, the classification of the sixth edition of the balance of payments compilation guide, it was based on sectors, maturity dates, currency and relative importance in the case of analytical studies related to the economic circumstances, exposure to risks and vulnerability to the interest rate risk. The consistent compilation when compiling the international investment position, as well as the other relevant accounts. So that it is possible to conduct a comprehensive analysis for the relationships among them. The consistent levels of details of the investment income and financial positions allows for estimating the rates of return. Hence, the international investment position data includes the details of instruments and sectors comprehensively, which in turn leads to the facilitation of the understanding of the interlinkages with the other data groups, such as monetary and financial statistics, and checking their accuracy. [8]

The international investment position and balance of payments transactions form together the national accounts group for the economy of any country. The international investment position in the main macro account that records the balance of international financial assets and liabilities for the country. The financial items of the international investment position are composed of commitments to the non-residents and obligations towards them. The tangible immovable assets (Monetary gold, Special Drawing Rights (SDRs) and lands) except what is owned for a foreign entity that is not under the authority of the regional boundaries like the possessions of an economic entity whose is located in the region. Therefore, the non-resident owner is treated as a holder of a financial right on the economy where it/he resides who has the ownership of the assets right and not on the basis that this owner owns the non-financial asset.

Besides, the sixth edition of the BOP compilation guide revealed that the international investment position shows the value and the composition of the financial assets for an economy that is represented by obligations on the nonresidents and the gold holding with the reserve assets category and by the commitments of the residents in a given economy to the non-residents [9]. The difference between the external assets and external liabilities for an economy is the net international investment position that might be positive or negative. The net wealth for any economy is composed of net international investment position:

$$
N W=I A B+I L B+N F A B
$$

Where,

NW: Net Wealth

IAB: International Assets Balance

ILB: International Liabilities Balance

NFAB: Net Financial Assets Balance

The relationship between investment income in the balance of payments accounts and the international investment position, especially the net investment income and net international investment positions, is characterized by interlacement and complexity. To reassure the importance of the consistency in compiling and classifying transactions and balances, both accounts are considered as an integrated group of account [10].

However, the sixth edition revealed that the investment income is classified with the functional categories of the financial assets and liabilities that is related to certain categories. Each category of the functional categories of assets encompasses various types of financial instruments that serves a certain purpose [11].

\subsection{The Mechanism of Recording Transactions in the Balance of Payments}

The direct foreign investment is calculated and measured by the balance of payments division in Statistics and Research Department at the Bank of Iraq using the information incoming from the concerned parties (banks, Iraq Stock Exchange). Consequently, the values of international transactions that belong to the outflow of foreign direct investment and the inflow of foreign direct investment according to the following mechanism:

a) Entering the data contained in the statements obtained from the relevant parties in the Central Bank of Iraq in a computer program designed for this purpose after sorting the transactions that are classified under the Foreign Direct Investment account by determining the purpose of the transfers.

b) Determining and verifying the type of transaction whether it represents a foreign direct investment flowing from Iraq to abroad or conversely a foreign direct investment flowing from outside Iraq into Iraq.

c) The foreign direct investment is then represented and confirmed in the balance of payments data in the amount of the outflow or the inflow, which represents either a credit or a debit entry annually.

d) The foreign direct investment is calculated by subtracting the liabilities inside the country (Iraq) from the assets abroad, to show the net foreign direct investment:

$$
N F D I=B A O U T-B L I N
$$

Where,

NFDI: Net foreign direct investment

ABOUT: Balance of assets outside the country

BLIN: Balance of liabilities inside the country

The balance of foreign direct investment shows within the 
international investment account in the financial account in cumulative values.

\subsection{The Effect of the Inflow of FDI into Iraq}

A general look at the flows of this investment indicates that the flows into the hosting country (i.e., the inflows) will have a positive effect on the balance of payments. Whereas the flows outside the country (i.e., the outflows) will have a negative effect on the balance of payments of the exporting country.

In order to identify the effects of the foreign direct investments on the Iraqi balance of payments in general and the financial account in particular, we will discuss the next topics.

\subsection{The Direct Effects of Foreign Direct Investment}

Table 1 and Figure 1 show that the outflow of foreign direct investment from Iraq during the period (2007-2014) ranged from US\$ 7.9 million as a minimum in 2007 to US\$ 489.5 million in 2012. They also show the total outflow for the whole period did not exceed US\$1,562.4 million. These outflows are weak when compared to the total inflows for the same period to Iraq that approximated US\$ 21,217.7 million - which is also not considered high in the absolute numbers.

Table 1. Net Foreign Direct Investment for Iraq (2005-2014)(US\$ Million).

\begin{tabular}{|c|c|c|c|c|c|}
\hline \multirow{2}{*}{ Year } & \multirow{2}{*}{ Foreign Direct Investment Inflow } & \multirow{2}{*}{ Foreign Direct Investment Outflow } & \multirow{2}{*}{ Outflow to Inflows Ratio (\%) } & \multicolumn{2}{|c|}{ Net Foreign Direct Investment } \\
\hline & & & & Surplus & Deficit \\
\hline 2005 & - & - & - & - & 515.3 \\
\hline 2006 & - & - & - & - & 78.0 \\
\hline 2007 & 971.8 & 7.9 & 0.8 & - & 963.9 \\
\hline 2008 & $1,855.7$ & 33.6 & 1.8 & - & $1,822.1$ \\
\hline 2009 & $1,598.3$ & 71.9 & 4.5 & - & $1,526.4$ \\
\hline 2010 & $1,396.2$ & 124.9 & 8.9 & - & $1,271.3$ \\
\hline 2011 & $2,082.3$ & 366.0 & 17.6 & - & $1,716.3$ \\
\hline 2012 & $3,400.4$ & 489.5 & 14.4 & - & $2,910.9$ \\
\hline 2013 & $4,131.2$ & 227.1 & 4.4 & - & $3,904.1$ \\
\hline 2014 & $4,781.8$ & 241.5 & 5.0 & - & $4,540.3$ \\
\hline Total & $21,217,7$ & $1,562,4$ & & & \\
\hline
\end{tabular}

The table was prepared by the researcher depending on the following:

Balance of payment for the Central Bank of Iraq (2005-2014). The CBI website and the General Directorate of Statistics and Research.

Note: for the years 2005 and 2006, the table shows only the net foreign direct investment as it did not show as an inflow and an outflow of investment in the balance of payments.

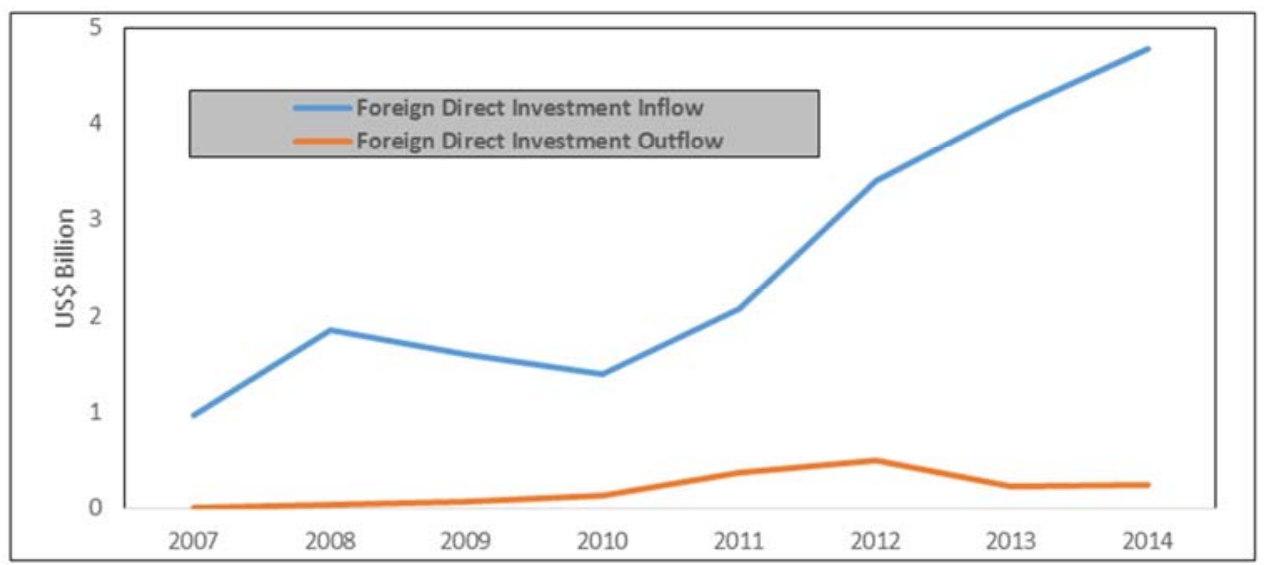

Figure 1. Net Foreign Direct Investment for Iraq (2005-2014)(US\$ Billion).

The primary effect of the inflows indicates the existence of an initial positive effect. But deeper analysis on the financial account components that includes besides the foreign direct investment the portfolio investment, other investments and reserve assets, that all show as net values, it could be noted that, in general, the effect of foreign direct investment during the period (2005-2014) was not positive. The net account registered a negative balance that ranged from US4 78.0 in 2006 and US\$ 4,941.1 million in 2013 - as shown in Table 2. In other words, the inflows into Iraq are higher that the outflows. This in turn created negative effects during the whole period on the financial account's surplus or deficit. The realized deficit in the net foreign direct investment account during the period (2005-2008) and the period (20112014) has contributed to a decline in the realized surplus in the net financial account by ratios that ranged from $0.6 \%$ in 2006 and $11.4 \%$ in 2012 . The realized deficit in the net foreign investment account during the periods (2009-2010) and (2013-2014) contribute to the increase in the financial account deficit by percentages that ranged from $21.1 \%$ in 2009 and $89.1 \%$ in 2013 - as shown in Table 2. 
Table 2. Financial Account for Iraq (2005-2014)(US\$ Million).

\begin{tabular}{llllllll}
\hline Year & $\begin{array}{l}\text { Net Direct } \\
\text { Investment }\end{array}$ & $\begin{array}{l}\text { Net Portfolio } \\
\text { Investment }\end{array}$ & $\begin{array}{l}\text { Net Other } \\
\text { Investments }\end{array}$ & Reserve Assets & Net Financial Account & $\begin{array}{l}\text { Net Direct Investment to Net } \\
\text { Financial Account Balance (\%) }\end{array}$ \\
\hline & & & & & Surplus & Deficit & \\
2005 & 515.3 & $-1,968.0$ & -345.0 & $-4,374.5$ & $-6,172.2$ & - & -8.3 \\
2006 & 78.0 & $-3,616.7$ & $-2,580.1$ & $-7,752.4$ & $-13,871.2$ & - & -0.6 \\
2007 & 963.9 & $-1,774.5$ & $-4,463.7$ & $-11,342.1$ & $-16,616.4$ & - & -5.8 \\
2008 & $1,822.1$ & $-2,805.5$ & -785.3 & $-18,650.4$ & $-20,419.1$ & - & -8.9 \\
2009 & $1,526.4$ & $3,681.4$ & $3,783.8$ & $5,817.3$ & & $7,241.3$ & 21.1 \\
2010 & $1,271.3$ & 795.4 & $5,642.5$ & $-6,266.0$ & & $1,443.2$ & 88.1 \\
2011 & $1,716.3$ & $-6,382.0$ & $-7,690.9$ & $-10,393.7$ & $-22,750.3$ & - & -7.5 \\
2012 & $2,910.9$ & $-5,672.1$ & $-13,414.8$ & $-9,254.7$ & $-25,430.7$ & - & -11.4 \\
2013 & $-4,904.1$ & $-14,317.9$ & $5,857.5$ & $7,860.9$ & & $-5,503.6$ & 89.1 \\
2014 & $-4,540.3$ & $-4,526.8$ & $5,482.2$ & $-11,877.8$ & & $-15,462.7$ & 29.4 \\
\hline
\end{tabular}

The table was prepared by the researcher depending on the Balance of payment for the Central Bank of Iraq (2005-2014). The CBI website and the General Directorate of Statistics and Research.

Note: the negative and positive signs from the year 2005 to the year 2012 are opposite to what they look like, the positive signs indicate deficits and negative signs indicate surpluses - according the balance of payments compilation guide in its fifth edition that was issued in 1993. However, starting from 2013 and after, the signs are compatible to what they look like: the positive signs indicate surpluses and the negative signs indicate deficits - according the balance of payments compilation guide in its sixth edition that was issued in 2009.

Generally, to analyze the reflections of the previous indicators on the Iraqi economy, it is noted that:

The National Income and GDP have increased from IQD 100,100,817 million and IQD 113,163,015 million respectively in 2007 to IQD 147,641,254 million and IQD $165,421,919$ million respectively, in 2008. Then they declined to IQD 120,429,277 million and IQD 134,264,467 million in 2009 million respectively. Before returning to rise again during the subsequent period. They reached IQD 243,518,659 million and IQD 272,998,466 million in 2013 respectively, an increase of $102.0 \%$ and $103 \%$ respectively. In 2014, they returned to the decline and reached IQD $230,310,053$ million and IQD 258,281,720 million respectively, a decline of $5.0 \%$ for both in 2014 , as shown in Table 3.

Table 3. National Income and Gross Domestic Product for Iraq (2005-2014)(IQD Million).

\begin{tabular}{lllll}
\hline \multirow{2}{*}{ Year } & National Income & Growth Rate & Gross domestic Product & Growth Rate \\
\cline { 2 - 5 } & Value & - & $113,163,015$ & - \\
\hline 2007 & $100,100,817$ & 47.0 & $165,421,919$ & 46.0 \\
2008 & $147,641,254$ & $(18.0)$ & $134,264,467$ & $(19.0)$ \\
2009 & $120,429,277$ & 22.0 & $163,926,504$ & 22.0 \\
2010 & $146,453,469$ & 31.0 & $217,091,235$ & 32.0 \\
2011 & $192,237,070$ & 18.0 & $255,460,518$ & 18.0 \\
2012 & $227,221,851$ & 7.0 & $272,998,466$ & 7.0 \\
2013 & $243,518,659$ & $(5.0)$ & $258,281,720$ & $(5.0)$ \\
2014 & $230,310,053$ & & & \\
\hline
\end{tabular}

The table was prepared by the researcher depending on the following sources:

Ministry of Planning, Central Statistical Organization, Indicators on the Economic and Social Situation in Iraq, 2016.

Ministry of Planning, Central Statistical Organization, Statistical Group for 2015, Chapter 14: National Accounts.

a) The GDP per capita GDP at current and constant prices increased from IQD 4,988 million and IQD 4,084 million respectively in 2010 to IQD 7,796 million and IQD 4,986 million respectively in 2013 at growth rates of $56.0 \%$ and $22.0 \%$ respectively. They declined IQD 7,191 million and IQD 4,829 million respectively in 2014 , attaining negative growth rates (contraction) of $8.0 \%$ and $3.0 \%$ respectively. b) The consumer price index (CPI) increased from 142.7 in 2013 to 145.9 in 2014, an increase of $2.2 \%$ representing the inflation rate.

c) The tax revenues declined from IQD 2,877 million in 2013 to IQD 2,531 million in 2014, at a decrease rate of $12 \%$. Table 4 shows the trends of the above indicators and net foreign direct investment for the period (20102014)

Table 4. GDP Per Capita at current and constant prices, Consumer Price Index, Tax Revenues and Net Foreign Investment for Iraq (2005-2014)(IQD Million, \%).

\begin{tabular}{|c|c|c|c|c|c|c|c|c|c|c|}
\hline \multirow{2}{*}{ Year } & \multicolumn{2}{|c|}{ GDP Per Capita } & \multicolumn{2}{|c|}{ GDP Per Capita } & \multicolumn{2}{|c|}{$\begin{array}{l}\text { Consumer Price Index } \\
\text { Inflation Rate }\end{array}$} & \multicolumn{2}{|c|}{ Tax Revenues } & \multicolumn{2}{|c|}{ Net Foreign Investment } \\
\hline & $\begin{array}{l}\text { Current } \\
\text { Prices }\end{array}$ & $\begin{array}{l}\text { Growth } \\
\text { Rate }\end{array}$ & $\begin{array}{l}\text { Constant } \\
\text { Prices }\end{array}$ & $\begin{array}{l}\text { Growth } \\
\text { Rate }\end{array}$ & $2007=100$ & $(\%)$ & & $\begin{array}{l}\text { Growth } \\
\text { Rate }\end{array}$ & & $\begin{array}{l}\text { Growth } \\
\text { Rate }\end{array}$ \\
\hline 2010 & 4,988 & & 4,084 & & 125 & & 1,310 & & 1,271 & \\
\hline 2011 & 6,519 & 30.7 & 4,280 & 4.8 & 132 & 5.6 & 1,784 & 36.2 & 1,716 & 35.0 \\
\hline
\end{tabular}




\begin{tabular}{|c|c|c|c|c|c|c|c|c|c|c|}
\hline \multirow{2}{*}{ Year } & \multicolumn{2}{|c|}{ GDP Per Capita } & \multicolumn{2}{|c|}{ GDP Per Capita } & \multicolumn{2}{|c|}{$\begin{array}{l}\text { Consumer Price Index } \\
\text { Inflation Rate }\end{array}$} & \multicolumn{2}{|c|}{ Tax Revenues } & \multicolumn{2}{|c|}{ Net Foreign Investment } \\
\hline & $\begin{array}{l}\text { Current } \\
\text { Prices }\end{array}$ & $\begin{array}{l}\text { Growth } \\
\text { Rate }\end{array}$ & $\begin{array}{l}\text { Constant } \\
\text { Prices }\end{array}$ & $\begin{array}{l}\text { Growth } \\
\text { Rate }\end{array}$ & $2007=100$ & $(\%)$ & & $\begin{array}{l}\text { Growth } \\
\text { Rate }\end{array}$ & & $\begin{array}{l}\text { Growth } \\
\text { Rate }\end{array}$ \\
\hline 2012 & 7,432 & 14.0 & 4,753 & 11.1 & 140 & 6.1 & 2,311 & 29.5 & 2,910 & 69.6 \\
\hline 2013 & 7,796 & 4.9 & 4,986 & 4.9 & 143 & 2.1 & 2,877 & 24.5 & 4,904 & 68.5 \\
\hline 2014 & 7,191 & $(7.8)$ & 4,829 & $(3.1)$ & 146 & 2.1 & 2,531 & $(12.0)$ & 4,540 & $(7.4)$ \\
\hline
\end{tabular}

The table was prepared by the researcher depending on the following sources:

Ministry of Planning, Central Statistical Organization, Statistical Group for 2015, Chapter 14: National Accounts.

It should be noted that the size of the inflows reflected in the financial account of the balance of payments does not always represent actual volume of direct foreign investments into the country, since these also depend on the other sources of funding in addition to inflows, Borrowing from local sources of funding is not included in foreign direct investment, whereas the borrowing from international capital markets is considered an addition to foreign direct investment, which virtually represents a commitment in the medium term for the hosting country to the outside world to pay off the investment in terms of yields from one hand and the potential for conversion of assets for these investments abroad in the event of liquidation of such investments or for any other reason in the future on the other hand. On the level of balances, they take the same direction of analysis as with the flows. The cumulative balance of the outflow of foreign direct investments during the period (2005-2015) approximated IQD 2,108.6 million, comprising about 7.9\% of the balance of inflows of foreign direct investment that approximated IQD 26,629.5 million during the same period Table 5 .

Table 5. Balance of Foreign Direct Investment Inflows and Outflows for Iraq (2005-2014) (US\$ Million).

\begin{tabular}{lll}
\hline Year & Balance of Foreign Direct Investment Inflow & Balance of Foreign Direct Investment Outflow \\
\hline 2005 & $1,760.3$ & 88.7 \\
2006 & $2,143.2$ & 393.7 \\
2007 & $3,115.1$ & 401.6 \\
2008 & $4,970.8$ & 435.2 \\
2009 & $6,569.1$ & 507.1 \\
2010 & $7,965.3$ & 632.0 \\
2011 & $9,847.6$ & 998.0 \\
2012 & $13,248.0$ & $1,487.5$ \\
2013 & $18,379.2$ & $1,714.6$ \\
2014 & $23,161.0$ & $1,956.1$ \\
2015 & $26,629.5$ & $2,108.6$ \\
\hline
\end{tabular}

The table was prepared by the researcher depending on the reports published by the International Monetary Fund and The United Nations Conference on Trade and Development (UNCTAD) for the period (2005-2015).

The total cost for foreign direct investments that flowed into Iraq during the mentioned period approximated US\$ 81.2 billion for 296 projects, centered in three major sectors of coal; oil and gas, real estate and chemicals composing $42.6 \%, 39.3 \%$ and $7.4 \%$ respectively. In this regard, United Arab Emirates, United States, United Kingdom, Netherlands, Russia, Lebanon, India, Switzerland, Australia and France are the main countries investing in Iraq based on the investment cost of the projects. United Arab Emirates, United States and the United Kingdom together accounted for $60.0 \%$ of the total foreign direct investment inflow. On the other hand, the number of Iraqi foreign direct investment projects outside Iraq did not exceed nine projects at a total cost of US\$ 222 million. The main receiving countries of these investments were the United Arab Emirates, the United Kingdom, Turkey, Jordan, Lebanon and Iran respectively. The share of the United Arab Emirates, the United Kingdom and Turkey together amounted to $82.0 \%$ of the total cost of the projects.

\subsection{The Indirect Effects of Foreign Direct Investment}

The effects of the foreign direct investment on the domestic economy is attained through its impact on and the contribution to net fixed capital formation. ${ }^{* *}$ This indicator provides a precise perception of the stock of fixed capital and the distribution of such stock by economic activity and type of capital, and hence the production frontier for the country in general. The annual additions to this capital accumulation are identified through the annual fixed capital formation. The stock of fixed capital or the net fixed capital contributes to the overall economic growth through the interaction between the multiplier and the accelerator in the economy, leading to a change in the value of the production and output as it represents a production capacity that when increase leads to an increase in the production. Consequently, this ultimately affects the other macroeconomic variables like exports and imports.

The analysis of the data of gross and net fixed capital formation reveals the following:

The gross fixed capital formation at constant prices of 2007 reached about IQD 53,563 billion in 2014. The

\footnotetext{
** The net fixed capital formation is defined as the total value of fixed assets that is used by the economic unit to practice its activity at a point in time after subtracting the cumulative depreciation of these assets at this point in time.
} 
contribution of the public sector and private sector amounted to $79.0 \%$ and $21.0 \%$ respectively. Whereas the gross fixed capital formation at current prices reached about IQD 59,228 billion in 2014. The contribution of the public sector and private sector amounted to $77.0 \%$ and $23.0 \%$ respectively.

Table 6. Gross Fixed Capital Formation at Constant 2007 Prices and Current Prices for Iraq (2006-2014) (IQD Million).

\begin{tabular}{|c|c|c|c|c|c|c|c|c|c|c|c|c|}
\hline \multirow{3}{*}{ Year } & \multicolumn{6}{|c|}{ Constant Prices $(2007=100)$} & \multicolumn{6}{|c|}{ Current Prices } \\
\hline & \multicolumn{2}{|c|}{ Public Sector } & \multicolumn{2}{|c|}{ Private Sector } & \multicolumn{2}{|l|}{ Total } & \multicolumn{2}{|c|}{ Public Sector } & \multicolumn{2}{|c|}{ Private Sector } & \multicolumn{2}{|l|}{ Total } \\
\hline & Value & $\%$ & Value & $\%$ & Value & $\&$ & Value & $\%$ & Value & $\%$ & Value & $\%$ \\
\hline 2006 & $16,837,603$ & - & 993.523 & - & $17,831,127$ & - & $16,013,395$ & - & 897,759 & - & $16,911,155$ & - \\
\hline 2007 & $6,861,135$ & $(59.0)$ & 669,365 & $(33.0)$ & $7,530,500$ & $(58.0)$ & $6,861,040$ & $(57.0)$ & 669,365 & $(25.0)$ & $7,530,404$ & $(55.0)$ \\
\hline 2008 & $20,554,543$ & 199.0 & 709,425 & 6.0 & $21,263,968$ & 182.0 & $22,455,103$ & 227.0 & 785,436 & 17.0 & $23,240,539$ & 209.0 \\
\hline 2009 & $11,254,116$ & $(45.0)$ & $1,164,869$ & 64.0 & $12,418,985$ & $(42.0)$ & $12,083,560$ & $(46.0)$ & $1,387,682$ & 77.0 & $13,471,242$ & $(42.0)$ \\
\hline 2010 & $24,400,333$ & 117.0 & $2,157,727$ & $(100.0)$ & $26,568,090$ & 114.0 & $24,173,486$ & 100.0 & $2,079,291$ & 50.0 & $26,256,777$ & 95.0 \\
\hline 2012 & $31,652,831$ & 27.0 & $3,381,095$ & 41.0 & $35,033,926$ & 28.0 & $33,274,364$ & 29.0 & $4,865,507$ & 94.0 & $38,139,871$ & 35.0 \\
\hline 2013 & $41,857,086$ & 32.0 & $8,428,008$ & 149.0 & $50,285,094$ & 44.0 & $45,086,546$ & 35.0 & $9,950,130$ & 105.0 & $55,036,676$ & 44.0 \\
\hline 2014 & $42,341,303$ & 1.0 & $11,221,403$ & 33.0 & $53,562,706$ & 7.0 & $45,697,810$ & 1.0 & $13,529,959$ & 36.0 & $59,227,769$ & 8.0 \\
\hline
\end{tabular}

The table was prepared by the researcher depending on the following sources:

Ministry of Planning, Central Statistical Organization, Statistical Group for 2015, Chapter 14: National Accounts.

Note: the 2014 data are primary because the annual report of the actual gross fixed capital formation for the year 2014 .

The net fixed capital formation at constant prices of 1988 reached about IQD 160.1 billion in 2014 . The contribution of the public sector and private sector amounted to $89.0 \%$ and $10.4 \%$ respectively Table 7 .

Table 7. Net Fixed Capital Formation at Constant 1988 Prices for Iraq (2006-2014) (IQD Thousands).

\begin{tabular}{|c|c|c|c|c|c|c|}
\hline \multirow{2}{*}{ Year } & \multicolumn{2}{|l|}{ Public Sector } & \multicolumn{2}{|c|}{ Private Sector } & \multicolumn{2}{|l|}{ Total } \\
\hline & Value & $\%$ & Value & $\%$ & Value & $\%$ \\
\hline 2006 & $50,706,312$ & - & $9,563,252$ & - & $60,269,564$ & - \\
\hline 2007 & $80,347,435$ & 58.0 & $9,363,010$ & $(2.0)$ & $89,710,445$ & 49.0 \\
\hline 2008 & $86,956,348$ & 8.0 & $9,219,338$ & $(2.0)$ & $96,175,686$ & 7.0 \\
\hline 2009 & $90,702,041$ & 4.0 & $9,089,503$ & $(1.0)$ & $99,791,544$ & 4.0 \\
\hline 2010 & $96,734,302$ & 7.0 & $8,912,987$ & $(2.0)$ & $105,647,289$ & 6.0 \\
\hline 2011 & $101,438,226$ & 5.0 & $9,076,073$ & 2.0 & $110,514,299$ & 5.0 \\
\hline 2013 & $130,670,861$ & 11.0 & $13,252,286$ & 35.0 & $143,923,147$ & 13.0 \\
\hline 2014 & $143,507,738$ & 10.0 & $16,617,847$ & 25.0 & $160,125,585$ & 11.0 \\
\hline
\end{tabular}

The table was prepared by the researcher depending on the following sources:

Ministry of Planning, Central Statistical Organization, Statistical Group for 2015, Chapter 14: National Accounts.

Note: the 2014 data are primary because the annual report of the actual gross fixed capital formation for the year 2014 .

a) The activities of social services, electricity, water, financing, mining, transportation, communication and warehousing occupied about $80.0 \%$ of the net fixed capital formation for the public and private sectors' activities. The contribution of these sectors is $36.0 \%$, $26.0 \%, 11.0 \%$ and $7.0 \%$ respectively. b) Three major assets occupied $77.0 \%$ of the net fixed capital formation. They are machinery and equipment, construction and non-residential buildings with shares of $51.3 \%, 13.9 \%$ and $11.8 \%$ respectively, as appears in Table 8.

Table 8. Net Fixed Capital Formation for the Public and Private Sectors for Iraq (2006-2014) (IQD Thousands).

\begin{tabular}{|c|c|c|c|c|c|c|c|c|c|}
\hline \multirow[t]{2}{*}{ Year } & $\begin{array}{l}\text { Residential } \\
\text { Buildings } \\
\end{array}$ & $\begin{array}{l}\text { Non-residential } \\
\text { Buildings }\end{array}$ & Constructions & Transportation & $\begin{array}{l}\text { Machinery and } \\
\text { Equipment }\end{array}$ & $\begin{array}{l}\text { Furniture and } \\
\text { Office Equipment }\end{array}$ & Assets & $\begin{array}{l}\text { Other } \\
\text { Assets }\end{array}$ & \multirow[t]{2}{*}{ Total } \\
\hline & 25 Years & 25 Years & 25 Years & 10 Years & 10 Years & 10 Years & 5 Years & 5 Years & \\
\hline 2006 & $10,118.1$ & $9,797.0$ & $13,528.3$ & $3,923.5$ & $15,292.3$ & $7,350.6$ & 71.1 & 188.7 & $60,269.6$ \\
\hline 2007 & $9,889.0$ & $12,499.7$ & $14,274.8$ & $6,692.0$ & $34,992.3$ & $11,009.0$ & 161.7 & 192.1 & $89,710.4$ \\
\hline 2008 & $9,593.5$ & $13,192.5$ & $13,953.0$ & $7,776.8$ & $40,002.9$ & $11,293.1$ & 165.9 & 198.0 & $96,175.7$ \\
\hline 2009 & $9,301.5$ & $13,667.0$ & $13,548.4$ & $8,852.5$ & $42,175.5$ & $11,874.1$ & 166.7 & 206.0 & $99,791.5$ \\
\hline 2010 & $9,104.6$ & $15,007.4$ & $14,293.5$ & $9,313.5$ & $46,228.5$ & $11,228.8$ & 178.7 & 292.3 & $105,647.3$ \\
\hline 2012 & $9,305.6$ & $16,376.6$ & $16,791.9$ & $11,400.9$ & $62,342.7$ & $10,879.2$ & 227.3 & 211.9 & $127,536.0$ \\
\hline 2013 & $9,747.4$ & $16,945.8$ & $20,688.6$ & $14,454.2$ & $70,984.9$ & $10,568.2$ & 247.7 & 286.2 & $143,923.1$ \\
\hline 2014 & $9,016.5$ & $18,899.2$ & $22,171.0$ & $18,550.9$ & $82,003.4$ & $8,863.7$ & 277.3 & 343.6 & $160,125.6$ \\
\hline
\end{tabular}

The table was prepared by the researcher depending on the following sources:

Ministry of Planning, Central Statistical Organization, Indicators on the Economic and Social Situation in Iraq, 2016. 
The indirect effects of the flow of foreign direct investments, contrary to the direct effects, do not show immediately and but take a lag to reflect on the balance of payments through the effect of the inflows and outflows on the trade of the hosting country. These inflows might affect the exchange rate of the hosting country's currency and, consequently, the prices of goods. In addition, the foreign direct investment incentivize the domestic production for exporting purposes or making up imports. The investing companies might use domestic goods whose production requires imported goods. Ultimately, the exports and imports of the hosting country is affected. The effect of the balance of payments in the medium and long term could be positive or negative depending on the extent of the needs of the investing enterprises for importing capital and intermediate goods and the extent of the availability of the industrial base and the labor force needed.

The previously mentioned effects on the current operations in the balance of payments account whether on the trade balance for the foreseen transactions or on service balance for the unforeseen transactions. Given that this impact varies from country to another depending on the nature of the investment enterprise, its purpose and duration.

Table 9 includes the trade balance and service balance in the current account and income in the Iraqi balance of payments. It is noticed that the effect of the trade balance on the current account balance during the period (2006-2014) was positive. It attained a surplus of US\$ $11,821.9$ million in 2006 and increased to US\$ $38,780.8$ in 2014, or an increase by $228.0 \%$. Regarding the service balance for the period (2006-2014), it achieved a deficit during the entire period increasing from US\$ 5,163.5 million in 2006 to US\$ 8,296 million in 2011 and US\$ 10,659.3 million in 2014 at rates of increase that approximated $61.0 \%$ and $28.0 \%$ respectively. Therefore, it effect on the current account was negative on the balance of the current account for the entire period.

Table 9. Iraqi Trade and Service Balances (2006-2014) (US\$ Million).

\begin{tabular}{|c|c|c|c|c|c|c|c|c|c|}
\hline \multirow[t]{2}{*}{ Year } & \multirow{2}{*}{$\begin{array}{l}\text { Current Account } \\
1+2+3+4\end{array}$} & \multicolumn{3}{|c|}{ Trade Balance (1) } & \multicolumn{3}{|c|}{ Service Balance (2) } & \multirow{2}{*}{ Income (3) } & \multirow{2}{*}{ Current Transfers (4) } \\
\hline & & Exports & Imports & Total & Receipts & Payments & Total & & \\
\hline 2006 & $7,095.6$ & $30,529.4$ & $18,707.5$ & $11,821.9$ & 357.0 & $5,520.5$ & $-5,163.5$ & 895.8 & -458.6 \\
\hline 2007 & $20,062.7$ & $39,587.0$ & $16,622.5$ & $22,964.5$ & 861.3 & $4,865.6$ & $-4,004.3$ & $1,483.0$ & -380.5 \\
\hline 2008 & $28,440.9$ & $63,726.0$ & $29,761.4$ & $33,964.6$ & $1,499.9$ & $7,573.3$ & $-6,073.4$ & $3,485.8$ & $-2,936.1$ \\
\hline 2009 & $-1,142.5$ & $39,430.4$ & $35,284.8$ & $4,145.6$ & $2,198.9$ & $8,583.7$ & $-6,384.8$ & $3,095.1$ & $-2,139.4$ \\
\hline 2010 & $6,477.4$ & $51,763.6$ & $37,328.0$ & $14,435.6$ & $2,835.3$ & $9,879.4$ & $-7,044.1$ & $1,593.2$ & $-2,507.3$ \\
\hline 2011 & $26,128.8$ & $79,680.5$ & $40,632.5$ & $39,048.0$ & $2,828.0$ & $11,124.0$ & $-8,296.0$ & -237.4 & $-4,385.8$ \\
\hline 2012 & $29,542.0$ & $94,208.6$ & $50,155.0$ & $44,053.6$ & $2,834.1$ & $13,292.9$ & $-10,458.8$ & $1,059.2$ & $-5,112.0$ \\
\hline 2013 & $22,590.3$ & $39,321.0$ & $89,767.9$ & $50,446.9$ & $3,298.0$ & $14,658.2$ & $-11,360.2$ & $-505.2+$ & $-4,865.3 \#$ \\
\hline 2014 & $24,427.9$ & $83,980.9$ & $45,200.1$ & $38,780.8$ & $4,131.0$ & $14,790.3$ & $-10,659.3$ & -530.8 & $-3,162.8$ \\
\hline
\end{tabular}

* Primary income. \# Secondary income.

The table was prepared by the researcher depending on the following source:

Balance of payment for the Central Bank of Iraq (2005-2014). The CBI website and the General Directorate of Statistics and Research.

Having touched on the direct effects and the indirect effects of foreign direct investment, the net effect is difficult to measure whether on the balance of payments or the overall indicators of the domestic economy, because this requires the determination of the difference between the effects of the current operation of such investment and the effects and processes achieved in the absence of this investment. This is because comparing inflows and outflows abstractly without taking into account what could happen as a result of reinvesting profits and the effects of foreign direct investment and its impact on foreign trade. However, initially, it is possible to identify the impacts through the size of these flows relative to the overall indicators in the economy. It can be noticed that there are two opposite directions. The data indicate that the ratio of foreign direct investment inflows to gross fixed capital formation and to GDP at current prices increased from $4.7 \%$ and $3.5 \%$ in 2005 to $9.6 \%$ and $15.7 \%$ in 2015 respectively. While the ratio of foreign direct investment outflows to the gross fixed capital formation at current prices decreased from $0.8 \%$ in 2005 to $0.4 \%$ in 2015 . However, it rose as a percentage of GDP from $00.2 \%$ in 2005 to $1.2 \%$ in 2015 , as shown in Table 10 .

Table 10. Inflow and Outflow of Foreign Direct Investment for Iraq (2006-2014) (\% of Gross Fixed Capital Formation and Gross Domestic Product).

\begin{tabular}{lllll}
\hline Year & \multicolumn{2}{l}{ FDI to Gross Domestic Products } & \multicolumn{2}{l}{ FDI to Gross Fixed Capital Formation } \\
\hline & Inflow & Outflow & Inflow & Outflow \\
\hline 2005 & 3.5 & 0.2 & 4.7 & 0.8 \\
2006 & 3.3 & 0.6 & 2.7 & 2.1 \\
2007 & 3.5 & 0.5 & 5.0 & - \\
2008 & 3.8 & 0.3 & 6.4 & 0.1 \\
2009 & 5.9 & 0.5 & 6.5 & 0.3 \\
2010 & 5.8 & 0.5 & 4.6 & 0.4 \\
2011 & 5.3 & 0.5 & 4.6 & 0.9 \\
2012 & 6.1 & 0.7 & 7.1 & 1.0 \\
2013 & 7.9 & 0.7 & 8.2 & 0.4 \\
2014 & 10.4 & 0.9 & 8.1 & 0.4 \\
\hline
\end{tabular}




\begin{tabular}{lllll}
\hline Year & FDI to Gross Domestic Products & \multicolumn{2}{l}{ FDI to Gross Fixed Capital Formation } \\
\hline & Inflow & Outflow & Inflow & Outflow \\
\hline 2015 & 15.7 & 1.2 & 9.6 & 0.4 \\
\hline
\end{tabular}

The table was prepared by the researcher depending on the reports published by the International Monetary Fund and The United Nations Conference on Trade and Development (UNCTAD) for the period (2005-2015).

\section{Conclusions}

a) The foreign direct investment is considered an asset for the economy of the exporting country and a liability for the economy in which the investment enterprise operates. The direct transactions of capital and equity are registered as dues on the asset side and obligations on the liabilities side. The changes in assets and liabilities are registered as separate entries under the "foreign direct investment abroad" item, and vice versa for the economy preparing the data about direct investment. However, the direct investment income, it appears as a net value for both parties (rights and obligations).

b) The net international investment position form a part of the general budget, where the value of non-financial assets to it to obtain the net value for the economy as a whole.

c) Regarding the calculation of foreign direct investment, it shows with the international investment account in the financial account on cumulative basis after calculating the net of this investment on annual basis through the settlement between the assets abroad and the liabilities inside the country.

d) The data approved by the Central Bank of Iraq about the foreign direct investment were confined to two sources. The first includes the statement of withdrawn outgoing transfers/ incoming transfers from abroad and the statement of sold foreign transfers/ the amount transferred outside Iraq that are sent by the banks. Whereas the second is the Iraq Stock Exchange data.

e) Despite the unfavorable circumstances in the investment environment and the political and economic environment, the directions of these investments highlighted Iraq as an important investment destination. This creates the incentive for developing this investment environment to attract these investments.

f) The foreign direct investment outflows from Iraq are considered weak. They did not exceed US\$ 1,562.4 million during the entire period of (2007-2014) forming $7.4 \%$ of total capital inflows inside Iraq which is already low. Its share of the total capital to all Arabic countries ranged from $1.2 \%$ in 2007 to $10.7 \%$ in 2014 . Therefore, the effect of these flows (inflows and outflows) on the financial account and the Iraqi balance of payments is generally weak. Despite the fact the initial effect of the inflows might signify positive impacts, the impact on the level of financial account components is generally negative during the entire period - meaning that the obligations resulting from the inflow are bigger than those from the outflows. g) There are no robust evidence that the increase in the national income and gross domestic product during the period (2007-2014) and the high per capita GDP on average in Iraq are all resultant from the transmission of the impact from the international economy to the domestic economy. This is due to the absence of mechanisms that guarantees such transmission, especially particularly Iraq is a one-sided economy.

h) The main effect of the foreign direct investment on the real sector appear through the indirect effect of this investment and its contribution in net fixed capital formation that contributes to the economic growth in general through the multiplier and the accelerator and hence this reflects on increasing production which in turn affect the other macroeconomic variables as exports and imports. Consequently, this reflects on the balance of payments generally. In this regard the net fixed capital formation for all activities increased from IQD 89,710 million in 2007 to IQD 160,126 million in 2014 , an increase by $78.0 \%$.

i) The net effect of foreign direct investment on the Iraqi balance of payments is generally difficult to measure. However, the effect could be generally realized through the ratio of the inflows and outflows to the macroeconomic indicators. In this regard, the ratio of foreign direct investment inflows to gross fixed capital formation and to GDP at current prices increased from $4.7 \%$ and $3.5 \%$ in 2005 to $9.6 \%$ and $15.7 \%$ in 2015 respectively. While the ratio of foreign direct investment outflows to the gross fixed capital formation at current prices decreased from $0.8 \%$ in 2005 to $0.4 \%$ in 2015 .

\section{Recommendations}

a) Reviewing the deterrents of foreign direct investment that were created by the international indicators to evaluate the investment climate in Iraq though, for example, diagnosing the weaknesses that made these deterrents real obstacles that is expelling for the foreign direct investment, and then determining the remedies that reverses the effects of these factors to become attractive factors in the future instead.

b) Forming a committee made up of members from the Central Bank of Iraq, Ministry of Planning and National Investment Commission, as well as the other relevant sectoral bodies in order to conduct a survey and collect data for the use in the balance of payments statistics and international investment position due to the growing complexities of transactions.

c) The Adoption and identification of specific mechanisms 
to ensure the transmission of the effects of the global economy through foreign direct investment to the domestic economy and the real sectors, so as to ensure initiating of effects on the financial account of the balance of payments and then stimulating indirect effects on the current account and the account services through affecting the macroeconomic variables like fixed capital formation as a production capacity that could be used to boost production and achieve growth.

\section{Acknowledgements}

We would like to thank Dr. Bassam Awad, the head of Systemic Risk and Macroprudential Policy Analysis Division at the Central Bank of Jordan (bra05@my.fsu.edu) for his valuable comments and review. All errors are ours.

\section{References}

[1] Brahim Guendouzi, Relations Economiques International Sons. 5th edition. Ager 2008.

[2] Driss, Slim. "L'attractivité des investissements directs étrangers industriels en Tunisie." Région et développement 25 (2007): 137-156.
[3] Alexander, Gordon J., William F. Sharpe, and Jeffery V. Bailey. Fundamentals of Investments/Fundamentos de Inversiones. Pearson Educación, 2003.

[4] Hung Jingo. Globalization of Capital, Studies on Economic Globalization. 2003.

[5] Alasrag, Hussien. "Foreign Direct Investment Development Policies in the Arab Countries." MPRA Paper, (83). [Online] Available: http://mpra.ub.uni-muenchen.de/2230/ (Mar, 2007) (2005).

[6] Daniels, Joseph, and David D. VanHoose. "International monetary and financial economics." (2005).

[7] Goldstein, Morris. Determinants and systemic consequences of international capital flows. Vol. 77. International Monetary Fund, 1991.

[8] OECD: Benchmark Definition of Foreign Direct investment. Fourth Edition, 2008.

[9] Raymond Vernon. The manager in the international Economy 7th edition. Prentice Hall International 1nc. London, UK, 1996.

[10] Robert J. Carbaugh, International Economics 1 (3d ed. 1989).

[11] Yaici Farid, precis de finance international.E. N. A. G. Agerie, 2008. 